\title{
EL NEGRO, EL NIÑO, WITCHCRAFT AND THE ABSENCE OF RAIN IN BOTSWANA
}

\author{
JAN-BART GEWALD
}

\begin{abstract}
In October 2000 the remains of 'El Negro', a Tswana man who, as a stuffed specimen, had been on public display in Europe for over 160 years, were flown from Spain to Botswana and given a state funeral in the capital Gaborone. In early 2001, as it became clear that the rains were failing, rumours started circulating in Gaborone that linked the coming of El Negro to the absence of rain. This article charts the progress of the rumours relating to El Negro, relates them to the broader issues of Tswana ethnology and contemporary history, and situates them in the context of popular consciousness, previous work conducted on rumour, and Radio trottoir. In conclusion, the article argues that the El Negro rumours allowed for the articulation of deep-seated grievances on the part of large sections of the population within the context of Tswana cultural thinking and discourse.
\end{abstract}

One wonders what must have gone through their minds as they tore out the insides of someone's brother, husband or father and stiffened him to put him as a public spectacle in a museum alongside other 'artefacts'. ${ }^{1}$

For more than a century, Europeans have gawked at the body of an African man and laughed their lungs out. ${ }^{2}$

IN THE FIRST SIX MONTHS OF 2000 THE REPUBLIC OF BOTSWANA was blessed by the arrival of extensive and long-lasting rains. ${ }^{3}$ In the second half of the year, the remains of 'El Negro', a man who had died 170 years before, were returned from Europe and buried in Tsholofelo Park in Gaborone, the capital of Botswana. In late 2000 and early 2001 the rains failed, and on 9 January 2001 rumours surfaced that blamed the arrival of El Negro for the failure of the rains.

One may wish to argue that what the rumours said could not possibly be true, but it is a fact that people were discussing these ideas and seeing the presence of El Negro as central to the absence of rain. People clearly saw

Jan-Bart Gewald is a historian at the University of Cologne. He would like to thank Ms Meiki Maotwe for first alerting him to this topic, Nancy Jacobs for suggesting that it was worth an article, African Affairs' anonymous reader, and Neil Parsons - the man who knows more about El Negro academically than anybody else - for news, views and critical suggestions.

1. The Voice, 6-12 October 2000, p. 6, editorial.

2. Mmegi, The Reporter, 6-12 October 2000, editorial.

3. To be sure, there were floods. Indeed, Gaborone, the capital of the Republic, was at one stage physically cut off from the outside world. 
the world and current issues in terms of these rumours. In this article I shall be discussing these rumours, and placing them in their context by relating them to the broader issues of Tswana ethnology and contemporary history. By so doing, insight will be provided into the way such rumours can come into being, and, perhaps more importantly, what these rumours have to say about the contemporary world. The article provides a summary overview of the absence of rain and the development of El Negro rumours in January 2001, followed by a discussion of rainmaking, magic and witchcraft in Tswana culture. Exactly who or what El Negro was, is outlined in the following section, after which the arrival of El Negro's remains in Botswana, and the shaming of Botswana, are described. Finally, the article seeks to situate the El Negro rumours in the context of popular consciousness, previous work conducted on rumour, and Radio trottoir. In conclusion, it argues that the El Negro rumours allowed for the articulation of deep-seated grievances on the part of large sections of the population within the context of Tswana cultural thinking and discourse.

\section{Rumours and rain}

In late 2000 as the skies remained clear in Gaborone, and the daily maximum temperatures continued to rise, it became clear to one and all in Botswana that the rains were failing to arrive. Shortly before Christmas rumours started to surface of young women who had been observed throwing salt into fires in such a way as to prevent the rains from coming and destroying their festive season hair-styles. ${ }^{4}$ Generally these rumours were told with a twinkle in the eye and a fair bit of good-natured banter regarding the irresponsibility of young people. However, on 9 January 2001 far more sinister rumours linking the absence of rain with the buried remains of El Negro started to emerge and develop. ${ }^{5}$ In essence these rumours argued that the return of the body was witchcraft that was stopping the rain from coming.

The El Negro rumours were spread throughout Gaborone and its satellite towns by means of the cut-throat efficiency of the privatized public transport system consisting of mini-buses that roar along set routes

4. Extensive braiding with extensions in a variety of colours appears to have been the fashion. Braiding is an expensive, long, and even painful operation which can take anything up to 8 hours. The advent of extensive rains with an increase in humidity would have changed the texture of the hair, necessitating continual alterations. In addition, the splendid hairdos would have remained hidden from sight for most of the time under plastic bags against the rain.

5. Though nobody I spoke to linked the two issues, it would seem more than coincidental that on the very date that the El Negro rumours first started to emerge, southern Africa, Botswana included, experienced a lunar eclipse. In the early evening the full moon rose blood red in colour in a cloudless sky, and for about three hours, displaying a series of colours ranging from green to pink, travelled through the shadow of the earth. 
throughout the day. ${ }^{6}$ Virtually everybody I spoke to mentioned that it was either in the mini-bus or at the taxi ranks that they first heard other people talking about El Negro and the absence of rain. Though people, with very few exceptions, did not claim to believe in the rumours, they were generally very willing to speak to me about what they claimed to have heard. ${ }^{7}$ Throughout 9, 10 and 11 January the El Negro rumours continued to spread and develop. On 12 and 13 January, it rained and the rumours seemed to disappear, in part because on 15 January, as one informant put it, 'It is Monday, people are tired after the weekend'. On the whole it appeared that the El Negro rumours had blown themselves out, that all the permutations and scandal had been explored, and that very little new would come of them unless new evidence arose. However, the rumours surfaced again briefly in a slightly different setting when it was reported on 16 January that people in the northeast of the country were facing starvation on account of the failure of the mopane worm to appear in sufficiently large numbers. The mopane worm is a moth larva which is collected and dried en masse as a highly sought source of animal protein. ${ }^{8}$ The absence of rain, which in the public's mind was linked to the presence of El Negro, also led to an absence of mopane worms. ${ }^{9}$

The gist of the El Negro rumours can be distilled into a number of components, some of which were excluded or included in the rumours, depending on whatever appeared to be most convincing. Thus the rumours nearly always carried variations of the four following points:

(i) The people of Botswana are poor, yet the government chose to purchase bones, a skull in particular, from another country at great cost. At the same time, there was a variation on the theme which alleged that the government had received substantial amounts of money in exchange for accepting the skull.

6. It is interesting to speculate that, in the very first week that most Batswana were back in the urban setting of Gaborone after a festive season generally spent in the rural areas, most people were still subconciously thoroughly infused with a mindset that continued to emphasize the importance of the metaphysical. It must not be forgotten that it in the rural setting of the village that most Batswana are confronted once again with their ancestors.

7. In total between 10 and 18 January 2000 , approximately 30 people were spoken to in informal settings ranging from liquor stores, butchers' shops and supermarkets, through to chats with domestic workers, gardeners, waiters and taxi-drivers.

8. The mopane worm, which in its dried form is also served as a bar snack similar in texture yet rather more tangy than American bar pretzels, is featured on the newly minted 5 Pula coin. 9. The Botswana Daily News, 16 January 2001, p. 3, carried an article entitled 'Batswana face phane crisis this year' which blamed the absence of worms on the over-exploitation by unscrupulous people of this limited natural resource. An academic was quoted as saying, 'It is about how people harvest the resource and not a problem of rainfall'. However, as one of my informants reminded me, with the infallible logic of a conspiracy, the government had brought El Negro to Botswana, and the Daily News was the government paper, so of course it would blame the absence of mopane worms on something else. 
(ii) However, the people of Botswana did not even know who the person was, for there were just bones. The remains are different from what the people saw in Spain. They could be anybody. They are the bones of a Bushman.

(iii) South Africa did not want them. Why not and what is it hiding from the people of Botswana?

(iv) Even so, the Botswana government flew the remains down at great expense and buried them with much pomp and ceremony, but the poor remain poor.

Hereafter the rumours developed along one or a combination of the following three strands:

(i) that the bones are those of a Bushman whose burial has greatly angered the ancestors, Chief Tshekedi Khama in particular; ${ }^{10}$

(ii) that the bones are part of an extremely powerful drug purchased by the ruling party to prevent the coming of the rains, in order to ensure the failure of the harvest, keep the people poor, maintain their dependence on the ruling party, and ensure its continued hold on power;

(iii) that the bones are those of a person who did not come from Botswana, and who has either upset the ancestors, or is himself extremely upset.

In essence what the people were discussing whilst driving in the mini-buses through the streets of Gaborone to and from work, was that whatever had been buried in Tsholofelo Park in Gaborone was something that prevented the rain from falling. Many people claimed that it was a powerful form of medicine that had been planted by the ruling Botswana Democratic Party, Domkrag. ${ }^{11}$ Underlying all of these fears was the common issue of not knowing exactly who or what these buried bones came from, and the inability of the populace at large to gain an insight into why these bones should have come to be buried in Gaborone.

10. Tshekedi Khama was the strict, powerful and highly respected Kgosi of the Bamangwato from the 1930 s to the 1950 s.

11. The symbol and popular name of the BDP is the manual jack, which used to be used to jack up wagons and trucks. The Setswana name Domkrag is derived from the Afrikaans and Dutch word which translates literally as 'stupid power'. In the run-up to the first democratic elections in Botswana in the early 1960s the term 'democracy', which was one of the rallying calls of the BDP, sounded like the powerful term Domkrag, the word stuck, and the BDP has led the Republic of Botswana through more than thirty years of prosperous multiparty democracy. 


\section{Rainmaking and death}

It has been noted of Tswana society that Kgosi ke kgosi ka batho - a chief is a chief by the grace of the people - but in return a chief must ensure an adequate rainfall. It was thus a lucky sign for Festus Mogae when it rained on the day when he was formally inaugurated as the President of Botswana following the general election early in 2000. In the past and the present the failure of rain, in a society where the word for blessing and good fortune - Pula - is the same as the word for rain, has reflected the failure of a chief and indicated that the land was impure or bewitched. ${ }^{12}$ Writing throughout much of the twentieth century, the grand old man of Tswana ethnology, Isaac Schapera, has emphasized time and again the central importance of rain and rainmaking ceremonies in Tswana society. ${ }^{13}$ Indeed, ceremonies connected with the bringing of rain were considered to be the most important rituals in which a chief could be involved. In the same way as the writings of Schapera confirmed the earlier observations of hunters and missionaries of the nineteenth and early twentieth centuries, so too the writings of the Comaroffs continue to emphasize the central importance of rain and rainmaking in contemporary Tswana society. ${ }^{14}$ The central importance of access to and control over rain was an issue that soon became apparent to European missionaries who started working within Tswana society in the early nineteenth century. Not surprisingly, baroka ba pula, rainmaking specialists, were accorded a high status in Tswana society, a position which the missionaries sought to acquire for themselves. ${ }^{15}$ At the risk of being accused of writing in the ethnographic present, I want to refer at length to a text written by Schapera in 1950, not because I wish to claim that Tswana society has remained unchanged, but to reiterate the central importance of rainmaking within Tswana society:

The chief had a special rain enclosure (segotlwana sa pula) behind the hut of his great wife, where several pots of rainmaking medicines were kept. Every year, before the

12. For a brief introduction to the history of Tswana and the importance of rainfall to southern African societies in general, see R. Ross, A Concise History of South Africa (Cambridge University Press, Cambridge, 1999), pp. 15-20. Incidentally, it is worth mentioning that Pula has been made the official term for Botswana's unit of currency.

13. For an overview of Isaac Schapera's work see the appropriately named, Pula: Botswana Fournal of African Studies 12, 1-2 (1998), which is a special issue in honour of Schapera's seventy-five years of scholarship and includes Schapera's bibliography as compiled by Suzette Heald, pp. 100-15. Also Isaac Schapera, "The "Little rain" (pulanyana) ceremony of the Bechuanaland BaKxatla', Bantu Studies 4 (1930), pp. 211-16. In addition, see A Handbook of Tswana Law and Custom (International Institute of African Languages and Culture, London, 1938); The Tswana (International African Institute, London, 1953), pp.22, 60.

14. Jean and John L. Comaroff, Of Revelation and Revolution: Christianity, colonialism, and consciousness in South Africa Vol. I (Chicago University Press, Chicago, 1991) p. 336, n. 20.

15. For a discussion on this topic, see Comaroff and Comaroff, Revelation and Revolution, pp. 206-13; and Paul Stuart Landau, The Realm of the Word: Language, gender, and Christianity in a southern African kingdom (James Currey, London, 1995) pp. 24-9. 
cultivating season started, the immature girls ceremonially brought water to the pots; they and the immature boys were then sent to sprinkle some of the contents over the fields and cross-roads near the capital. If the rain did not come, driftwood and other objects connected with water were burned in the enclosure, so that the smoke should summon the clouds; sometimes, too, men were sent to capture alive a wild animal of a specified species and sex, which was then slaughtered, portions of its flesh being added to the mixture in the pots. Failing this, the women would gather at the graves of the chief's ancestors and, sprinkling them with water and beer, would sing special songs of prayer for rain. Ultimately the chief himself would go to one of the graves, accompanied by the people; there an unblemished black bull was slaughtered, and portions of its meat, the skin, bones, etc., were burned on the grave; and as the smoke rose, he would pray to his ancestor 'to let the rain fall'. As a last resort, search would be made for objects out of place (e.g. a pot hidden in a tree), which were thought to have been deposited by sorcerers to keep off the rain; such objects were doctored and thrown into a river bed or pool, and the people then gathered at the tribal councilplace to be sprinkled with the contents of the rain pots and freed from contamination. Throughout the rainy season, too, all newly bereaved people were reported to the chief, on whose instructions they were smeared with the juice of irritant bulbs used as rainmaking medicines; this treatment was intended to 'cool' their bodies and prevent them from scorching the land wherever they went. ${ }^{16}$

In essence the person who controlled rain could also determine the course of society.

As with all aspects of life, death in Tswana society was inextricably linked to rain. The spirits of the dead needed to be domesticated. Failure to do so could lead to all manner of misfortune, of which the worst was the absence of rain. ${ }^{17}$ It was the duty of the deceased's maternal uncle to ensure that a dead person was buried properly. As one of Schapera's informants put it in the 1940s, it was the maternal uncle's duty 'to handle the putrefaction of his sister's children'. ${ }^{18}$ The spirits of the dead, badimo, it was held, lived in a parallel world, similar to all intents and purposes to that of the living: indeed, a world 'where a man would continue to herd his grandfather's cattle and a woman to cultivate the soil'. ${ }^{19}$ However, the spirits of the dead took a keen interest in the world of the living and could influence and determine events in the living world:

They rewarded with good health and prosperity those who treated them with becoming respect and obedience, but punished with sickness, economic loss, or some other misfortune those who neglected them or who offended against the prevailing social code, of which they were the guardians. Hence, in order to retain their favour, they had to be specially propitiated. ${ }^{20}$

16. Schapera, The Tswana, p. 60 .

17. Comaroff and Comaroff, Revelation and Revolution, pp. 153-5.

18. Schapera, The Tswana, p. 59.

19. Schapera, The Tswana, p. 59.

20. Schapera, The Tswana, p. 59. 
The term sepoko (pl. dipoko), undoubtedly derived from the Dutch spook, ghost, is currently used to refer to the spirits of those dead who come back to trouble the living. Dipoko are held to rest in the ground during the day and to emerge at night to avenge wrongdoing done to them and to seek that which they desired or possessed in life. In the urban setting of Gaborone, it is reported that dipoko can also manifest themselves in the bodies of animals, particularly owls, cats and dogs, and that there are times when they appear to the living in the day-time. ${ }^{21}$ In addition, there are stories of phantom cars and phantom hitch-hikers that are also classified as dipoko.

Writing of surviving relatives, Schapera noted that their blood was believed to be 'hot'. Consequently it was believed that, should such a person wander about, there was a distinct danger that they would injure people, cattle, and crops - the mainstay of Tswana society in the past - and most importantly, they would keep away the rain, for wherever they trod the ground would become scorched. ${ }^{22}$ It was therefore essential that such a person should be taken to be 'cured' immediately:

This was formerly considered so important, particularly because of the dangers threatening the rain, that the chief or village headman, as soon as any death was reported to him, would himself send one of the recognised 'tribal doctors' to purify the survivor. ${ }^{23}$

Such a person would be confined to his/her homestead and subjected to a series of taboos and restrictions until they had been purified. Though the purification ceremonies differed from doctor to doctor, the general procedure followed was fundamentally the same. The roots and bulbs of certain plants, 'especially those used in making rain', would be used to purify the mourner, in such a way that their blood would no longer be hot and threaten the arrival of rain. ${ }^{24}$

Failure to observe the correct rites and practices associated with the stages through which human beings moved from life through death to an existence as ancestor, could threaten the whole society through the absence of rain. To prevent this from occurring everyone in the society watched anxiously to ensure the correct behaviour of all, and expected and called upon dingaka (ritual specialists) and dikgosi (chiefs) to ensure that this happened. Not surprisingly, those who consciously sought to stop rain were guilty of the most extreme form of witchcraft, for this was an activity that threatened the course of life and society as a whole.

21. Interviews and pers.comm. with Gladys Maotwe and Godfrey Koketso; Schapera, The Tswana, p. 61.

22. Isaac Schapera, Married Life in an African Tribe (first published 1940; Penguin edn., Harmondsworth, 1971), p. 279.

23. Schapera, Married Life, p. 279.

24. Schapera, Married Life, p. 280. 


\section{Witchcraft and magic}

At present the issues of witchcraft and ritual murder are very much part of everyday life for most people living in southern Africa, including the Republic of Botswana. ${ }^{25}$ In discussing the state and witchcraft, Cyprian Fisiy put the case even more strongly when he referred to mass circulation papers in Africa and stated that 'There is an indication that witchcraft and sorcery discourses constitute the primary concern of most African communities'. ${ }^{26}$

On the same days that El Negro was being discussed and described in the rumours circulating among the commuters of Gaborone, one of Botswana's quality papers carried an article covering the crash landing of wizards on to buildings in Zambia. ${ }^{27}$ In addition, the paper reported the ritual murder of a person for body parts in Mochudi, Botswana. Police were reported as looking for the murderer of the appropriately named Mr Bongi Moloi (Moloi being the Tswana term for sorcerer or witch). ${ }^{28}$ Assistant Commissioner K. Japinga of the Botswana police was quoted as saying, 'We normally reach that conclusion [that he was murdered for ritual purposes]

25. For some contemporary work on witchcraft and ritual murder, see Elizabeth Eldredge, 'Unmasking colonial rule: murder and the use of terror in British Basutoland, 1940-1960', paper presented at the 43rd Annual Meeting of the African Studies Association, Nashville, Tennessee, 16-19 November 2000; Cyprian F. Fisiy, 'Law out of context: witchcraft trials in Cameroon', paper presented at the ASA Annual Meeting, Toronto, 3-6 November 1994; Roger Gocking, 'A chieftaincy dispute and ritual murder in Elmina Ghana, 1945-46', paper presented at the ASA Annual Meeting, San Francisco, 25 November 1996; Birgit Meyer, 'The power of money, politics, sorcery, and pentecostalism in Ghana', paper presented at the ASA Annual Meeting, Columbus, Ohio, 13-16 November 1997; Bradford Strickland, 'Witchcraft and AIDS: some negotiations of power among the Kunda of eastern Zambia', paper presented at the ASA Annual Meeting, Toronto, November 1994, and 'Situating the moral ambiguities of Mankwala and witchcraft in Zambian ethnography', paper presented at the ASA Annual Meeting, Orlando, Florida; Luise White, 'The traffic in heads: bodies, borders and the articulation of regional histories', fournal of Southern African Studies 23, 2 (1997), pp. 325-38. Of particular importance and influence in the current discussion relating to witchcraft in Africa at present has been the work of Cyprian Fisiy and Peter Geschiere. Peter Geschiere and Cyprian Fisiy, 'Domesticating personal violence: witchcraft, courts and confessions in Cameroon', Africa 64, 3 (1994), pp. 321-41; Peter Geschiere, The Modernity of Witchcraft: Politics and the occult in postcolonial Africa (University Press of Virginia, Charlottesville, VA, 1997). 26. Fisiy, 'Law out of context', p. 2, n.1.

27. There have also been reports of a group of sorcerers from the town of Maun who flew down to Gaborone in either 1998 or 1999 . These sorcerers were reported to have flown on blankets, and one of them is said to have crash-landed in the low-income residential area of Old Naledi after he had swerved to avoid crashing into Kgale hill. The sorcerer was reported to have worn bracelets, anklets, necklace and belt fashioned out of human fingers. My informants claimed that after the man had been arrested he was clothed and released by the police. Batswana sorcerers are also reported to have flown on loaves of bread.

28. The Phuthadikobo Museum in Mochudi, the town where Mr Moloi was murdered, has a number of photographs on display of Bakgatla rainmakers in the 1930s, in addition to a collection of rainmaking pots. 
after we have found out that the body parts were removed by hand'. ${ }^{29}$ Recently a newspaper article reported the arrest of two men in Gantsi who 'cut off women's breasts and male private parts from fresh corpses in the mortuary'. The men were arrested after they had been found in possession of human remains which they were trying to sell to a 'traditional doctor in the village'. ${ }^{30}$ On a more innocuous note Batswana youth, in a manner not unlike that of their Gothic rock counterparts in northern Europe, flirt with the occult, as is made clear by the rapper Aka Bloode, who was recently the lead singer of the Wizards of the Desert. ${ }^{31}$

The use of magic may not necessarily be for evil purposes. In the past and at present Tswana magic consists primarily of the use of 'medicines (dithlare) for the attainment of certain specific ends which cannot be achieved by empirical methods alone'. ${ }^{32}$ Medicines can be used for all kinds of purposes - protecting a newly acquired motor-vehicle, improving one's health, acquiring the affections of a specific person, success in business and at school, or enhancing the fertility of livestock. The corollary is, of course, that medicines can also be used destructively. Though any person can fashion and prepare medicines, there are specialists, dingaka (sing. ngaka), to whom people can turn for professional advice. ${ }^{33}$ Amongst the dingaka there are those who practise divination through the use of specialized tokens made of bone, wood, ivory and the like, which are cast in such a way as to be used to determine insight into all manner of issues, be it wrongdoing in the past, possible future scenarios, or current situations.

In the ethnographic literature on Tswana society there is extensive reference to magic that is used maliciously. The Tswana term Boloi is used to refer to the practice which is translated as sorcery in English, whilst its practitioners are referred to as Baloi (sing. Moloi). Both men and women can become Baloi. There are two main categories of Baloi, those of the night and those of the day. Baloi consciously practise witchcraft out of motives of greed, jealousy and the like. ${ }^{34}$ As with witches elsewhere in the world, Baloi

29. The Botswana Gazette, 10 January 2001, p. 3, 'Ritual murder confirmed in Mochudi', by Ditso Anneleng; and on page 8 in the 'Science' section of the paper an article entitled 'Wizards: Zambians amazed by crash-landing flying wizards', a syndicated article by Pana/misanet. The Botswana Gazette can be accessed at the website www.gazette.bw. Later reports noted that Mr Moloi's penis, tongue and armpits had been cut out. Botswana Gazette, 17 January 2001, pp. 1-3.

30. 'Two Gantsi men suspected of cutting out organs from corpses in mortuary', Botswana Gazette, 18 April 2001, p. 5.

31. 'Bloode is too "nasty" for the Wizards!', Botswana Gazette, 31 January 2001, p. E2. That the Wizards of the Desert are well aware of their flirtation is evidenced by their recent album, Sangoma, which roughly translates as diviner, traditional doctor, spirit medium. See the recent discussion on H-SAFRICA@H-NET.MSU.EDU dealing with the origin of the word 'Sangoma'.

32. Schapera, The Tswana, p. 61.

33. Schapera, The Tswana, pp. 61-6.

34. Schapera, The Tswana, p. 65. 
have familiars, are able to fly, can disappear, cast spells, prepare and use medicines for unjust purposes, and transform people into the living dead, Mathlowane. Botswana has a corpus of legislation against witchcraft, yet, as the murder of Mr Moloi and the rumours accompanying El Negro indicate, witchcraft is very much a part of everyday life in the country at present.

Belief in and the practice of witchcraft extend across all levels of contemporary Batswana society. A few years ago students at the university of Botswana rioted because of the ritual murder of a young girl in Mochudi, the same settlement where Mr Moloi was recently murdered. In November 1994 the mutilated body of Segametsi Mogomotsi was found; in due course the girl's stepfather was arrested. Initially the stepfather confessed to the ritual murder of Segametsi and implicated a number of well-known business people in the deed. However, he soon retracted his statement:

In contrast with the graphic and gruesome description he had previously given of their involvement in his daughter's murder, he now stated that he had no evidence to suggest that any of them might have been involved. He explained to the police that a traditional doctor had told him that Segametsi had been killed by three men and a woman and that all these unnamed people were involved with new business enterprises. He himself had then concluded that the people he had previously named must be the ones to whom the traditional doctor had referred. ${ }^{35}$

All the people mentioned were arrested, but all apart from the stepfather were released for lack of evidence. In late January 1995, schoolchildren from the school which Segametsi had attended marched to the District Commissioner's office to present a petition demanding a more detailed investigation into the murder of the schoolgirl. The marchers clashed with police and full-scale rioting broke out; the businesses and houses of the principal suspects were burnt. Though the Special Support Group (paramilitary police) were deployed, and government ministers and the Attorney General travelled to Mochudi and addressed the populace, the tension did not abate. As a commentator noted:

In the absence of meaningful information from the police, the populace simply provided its own. As these stories gathered both momentum and corroborative detail, they became accepted as unchallengeable fact. If they were not true, it was asked, why would everyone believe them to be true? And because they were therefore true, it automatically followed that those who had been arrested by the police were the undoubted murderers. ${ }^{36}$

Though, by the use of force, the authorities were able to quash the unrest in Mochudi, further rioting and unrest soon spread. In Gaborone a self-styled

35. Sandy Grant, Etcetera: Events, issues, places and people of Botswana (Leitlho Publications, Odi, 1998), p. 167.

36. Grant, Etcetera, p. 170. 
Revolutionary War Council distributed pamphlets calling for a mass demonstration and demanding 'that justice should take its course without [the] state's intervention'. University of Botswana students broke into and disrupted a working session of the National Assembly. A rioting mob, pursued by tear gas-firing members of the Special Support Group, tore through the central business district of Gaborone. On 19 February, as rioting continued to spread, the President addressed the nation in a radio broadcast, and announced that the police and the army had been instructed to restore law and order in the country. ${ }^{37}$

In view of the fact that Botswana has the well-earned reputation of a country with respect for the rule of law, a high level of social tolerance, and a distinct dislike of violence, the events of early 1995 indicate the extent to which people felt threatened by what was perceived to be government collusion in the practice of witchcraft. The murder of Segametsi, or more precisely the failure of the established authorities to bring to book the perpetrators of the crime, highlighted the extent to which witchcraft was seen to be part and parcel of the established elite. Recent work by Elizabeth Eldredge on ritual murder in colonial Basotuland has specifically outlined the conscious involvement by the elite of many people in a community in the committing of ritual murder. That is, that the actual act, the breaking of extreme taboos and the involvement of many people, ensures the further compliance of many more. ${ }^{38}$ It was the children of Segametsi's school who called for further investigations into the murder. ${ }^{39}$ When they were met only with repression and silence, others who felt that they too were excluded and unheard joined them. ${ }^{40}$

\section{Who or what is El Negro? ${ }^{41}$}

The man who became El Negro may not have had a very long mortal life, but he has certainly had a longer historical life than most. After having died and been buried in 1830 he was immediately exhumed, exported to Europe and put on display.

37. Grant, Etcetera, p. 175.

38. Eldredge, 'Unmasking colonial rule'.

39. In a way that mirrors the findings of Jean and John L. Comaroff, 'Occult economies and the violence of abstraction: notes from the South African postcolony', American Ethnologist 26, 2 (1999), pp. 279-303.

40. Particularly disconcerting at present is the continued ritual murder of innocents in Mochudi. On 8 January 2001 the badly decomposed body of eight-year-old Brenda Bokole was found near the village. At least one informant claimed that El Negro, whose body had been similarly abused, had caused the rain to stop falling so as to draw attention to and express his anger about the continued witchcraft and ritual murder in Mochudi. 'Police about to crack ritual murder case?', Mmegi, The Reporter, 9-15 February 2001, p. 3.

41. Virtually all the information included in this section has been based on the work of Neil Parsons, pers. comm., paper and website. Anybody wishing to discover further insight into the history of El Negro could do no better than to access his El Negro website at http://ubh.tripod.com/afhist/elnegro/eln0.htm. 
At present the evidence indicates that the man who became El Negro was associated with a Tswana Batlhaping community that lived around the confluence of the Orange and Vaal rivers. The former village of Kgatlane has been identified as the most likely place from which El Negro was stolen. The ruins of the village are to be found in the vicinity of the present town of Douglas. ${ }^{42}$ This is across the Cape colonial boundary, in present-day South Africa. Besides being in contact with the Cape Colony, it is likely that the man concerned had been in contact with members of the London Missionary Society, and was possibly even one of the initial converts to Christianity. ${ }^{43}$ It has been suggested that the man's contacts with Christianity and the Colony could have brought him into contact with the Verraux brothers, French taxidermists who visited southern Africa earlier in the nineteenth century to collect zoological specimens. ${ }^{44}$

In 1830 the man died of some respiratory ailment. ${ }^{45}$ On the night of his burial the Verraux brothers dug him up, undoubtedly gutted him, placed him in preservatives and transported him to Cape Town. ${ }^{46}$ After having completed their collecting activities in the Cape Colony the brothers returned to France, where they were met with great acclaim. In contrast to many others who had returned from Africa with live or stuffed 'Bushmen', the Verraux brothers returned with a stuffed specimen of a new group of people, namely the Tswana. The young man who would later become known as El Negro was put on display in a shop in Paris to exhibit to the world the taxidermy skills of the brothers. ${ }^{47}$ Following the deaths of the Verraux brothers El Negro came into the possession of Francesco Darder, a medical doctor from Spain, who put 'El Betchuanas' on display at the 1888 World Exhibition in Barcelona. ${ }^{48}$ After the death of the doctor, El Betchuanas was

42. http://ubh.tripod.com/afhist/elnegro/eln05.htm.

43. On the coming of Christianity and its reception amongst the Tswana, see Comaroff and Comaroff, Of Revelation and Revolution, Vol. I. and Vol. II. Of Revelation and Revolution: The dialectics of modernity on a South African frontier (University of Chicago Press, Chicago, 1997); Landau, The Realm of the Word.

44. http://ubh.tripod.com/afhist/elnegro/eln03.htm.

45. http://ubh.tripod.com/afhist/elnegro/eln-pm.htm.

46. On the stealing of bodies and body parts from southern Africa, see Martin Legassick and Ciraj Rassool, 'Skeletons in the cupboard: museums and the incipient trade in human remains, 1907-1917', paper presented at the biennial conference of the South African Historical Society, 'Not telling: secrecy, lies and history', University of the Western Cape, 11-14 July 1999.

47. http://ubh.tripod.com/afhist/elnegro/eln07.htm. Le Constitutionnel, fournal du Commerce, Politique et Littéraire (Paris, rue Montmartre), no. 319, 15 November 1831: 'But their greatest curiosity is an individual of the nation of the Betjouanas. This man is preserved by the means by which naturalists prepare their specimens and reconstitute their form and, so to speak, their inert life. He is of small stature, black of skin, his head covered by short woolly and curly hair, armed with arrows and a lance, clothed in antelope skin, [with a bag?] made of bush-pig, full of small glass-beads, seeds, and small bones. Another thing that we are rather embarrassed to find a suitable term to characterise, is the very special accessory of modest clothing worn by the Betjouanas, which we find most striking.'

48. http://ubh.tripod.com/afhist/elnegro/eln01.htm. 
bequeathed to a small museum which was established in the doctor's honour in the small town of Banyoles in Spain. ${ }^{49}$

From 1916 until 1998, the body of the young man from Kgatlane was the star exhibit of the municipal museum in Banyoles. Throughout the years thousands of tourists gawked at 'El Betchuanas', and scores of schoolchildren were led past the display and shown an example of an African man. However, at some stage in the 1930s, possibly owing to an even more intense interest in race, the body was removed from its case, painted black and put back on display as El Negro. In 1991, in the run-up to the 1992 Olympic Games to be held in Barcelona, a certain Alphonse Arcelin, a medical doctor practising in the area, began demanding that an end be put to the degrading display. Arcelin's calls were greeted with intense support on the part of African countries and the Organization of African Unity: indeed, there were even calls for an African boycott of the Games. However, the response of Banyoles town council was all that it should not have been. Councillor Carles Abella was reported as stating: 'El Negro is our property. It's our business and nobody else's. The talk of racism is absurd. Anyway, human rights only apply to living people, not dead. ${ }^{50}$

In addition, Abella, who is also the biologist-curator of the museum, justified the continued exhibition of El Negro on the following grounds:

The black man of the museum forms part of the city's popular culture taught in school - of course we don't consider it [racist] - this is a museum that shows different races and cultures with adequate respect. It is a racial exhibit, and racism or morbidity may be a personal attitude of visitors which the museum does not foment. ${ }^{51}$

Equally remarkable were the words of the town's mayor: 'We have mummies and skulls and even human skins in the museum. What is the difference between those things and a stuffed African?'52

The barbarity and condescension of Banyoles town council were shared, it appears, by a large section of the town's business community, some of whom took to selling chocolates in the shape of El Negro, as well as T-shirts and balloons bearing slogans calling for the retention of El Negro. ${ }^{53}$ Now

49. Neil Parsons, 'El Negro/El Negre of Banyoles: Bushman from Bechuanaland, or Bechuana from Bushmanland?', paper presented at the University of Botswana History \& Archaeology Research Seminar, 30 March 2000. A full copy of the paper is to be found at http://ubh.tripod.com/news/banyol3.htm.

50. Parsons, 'El Negro', p. 2.

51. Parsons, 'El Negro', p. 3.

52. Parsons, 'El Negro', p. 2. A close look at some of the photographs taken inside the museum does indeed show the spreadeagled skins of at least two fully grown people stretched out on both sides of an arch leading from one display hall into another. From whom these skins were taken is as yet unknown.

53. Parsons, 'El Negro', p. 3. 
that El Negro has been returned to Africa, a replica has been erected in one of the town's drinking establishments. ${ }^{54}$

The Organization of African Unity called for the repatriation of El Negro to Africa, and Botswana was selected as the country to which the body was to be returned. At this stage, evidently hoping to frustrate the activities of the OAU, the museum's conservator stated that, on the basis of the shape of El Negro's skull, he must have been a 'Bushman'. As Neil Parsons put it:

The rearguard defence against repatriation ... resorted to another ploy to keep the body in Banyoles - that since El Negro is still really a 'Bushman' from the Kalahari, Botswana should be punished for its maltreatment of 'Bushmen' today by Banyoles withholding the body from repatriation. ${ }^{55}$

In the event, the Spanish central government took over and arranged for the repatriation of El Negro to Botswana.

\section{The arrival of El Negro}

Initially, in the run-up to the arrival of El Negro in Botswana on 4 October 2000, there was very little public interest. But a series of programmes on Radio Botswana during the long weekend associated with the Independence Day celebrations of 30 September, ensured that El Negro was on everybody's lips by the time his remains arrived in Gaborone. ${ }^{56}$

The Foreign Affairs Minister of Botswana, Lt.-Gen. Mompati Merafhe, senior government officials, members of the diplomatic community, hundreds of Batswana, and a guard of honour from the Botswana Defence Force were on hand to greet the arrival of El Negro at Gaborone's Sir Seretse Khama international airport. After the initial shock at the emergence of a small casket from the aircraft, as opposed to a full-length coffin, the remains were transported to lie in state at the civic centre in down-town Gaborone. From the early afternoon of 4 October through to the next morning, tens of thousands of Batswana queued in orderly lines to view and pay their last respects to El Negro. What the people got to see was not what they had expected. Everybody had expected the arrival of a body; instead what they saw was a skull stripped of its flesh. ${ }^{57}$ As the government paper put it:

54. http://ubh.tripod.com/afhist/elnegro/eln0.htm.

55. Parsons, 'El Negro', p. 7.

56. Long weekends and holidays are times when the recently urbanized inhabitants of Gaborone generally return to their home villages in the rural areas. Here, in the absence of the popular commercial FM radio stations, people while away their time listening to the programmes of Radio Botswana, which also broadcasts on short wave.

57. Personal observation on 4 and 5 October 2000. 
Some Batswana who had expected to see a mummified body of El Negro were disappointed at the civic centre where it was lying in state, to find that the remains did not have any flesh on them. They expressed doubt as to whether what is contained in a rather small casket were the remains of El Negro or something artificial. ${ }^{58}$

It turned out that, at some stage between the time when El Negro had been removed from display in Banyoles and his arrival in Gaborone, the remains of his hair, nails, soft tissue, flesh and so forth had been removed. Director of the National Museum Ms Tiki Pule attempted to find out where and why this had occurred, but was greeted with indifference and alleged misunderstanding on the part of her Spanish colleagues from the national museum in Madrid. Similarly Dr Alinah Segobye, archaeologist and acting head of the history department at the University of Botswana, was unable, not for want of trying, to discover what had happened to El Negro, where and why, following his removal from display in Banyoles in $1998 .^{59}$ It is most probable that El Negro was stripped of his last remaining soft tissue, nails and hair in Madrid. In addition, he was robbed of the grave goods he was buried with in 1830, and with which he had been put on display in Banyoles.

On the morning of 5 October 2000 the small casket bearing the remains was laid to rest in a full-length grave in Tsholofelo Park, Gaborone, the main attraction of which is a gaudily painted model of a rocket pointing up to the heavens. In the weeks and months that followed El Negro entered into the public consciousness of Batswana. Rioting students referred to one of their more tattily clad comrades as El Negro. People attending the funerals or weddings of those unfortunate enough not to have families referred to these as being El Negro. Yet by and large, the cars continued to roar past Tsholofelo Park and the physical remains of El Negro in Botswana's soil appeared to be forgotten.

\section{The shaming of Botswana}

In dealing with the development of rumours relating to El Negro and the absence of rain, it is essential that the following should be borne in mind. The El Negro that people had in mind, the stuffed body of a Tswana man, which is what he had been described as by those who had seen him on display in Banyoles, or as he had been portrayed in photographs of the display, was radically different from the small pathetic bunch of scraped bones that was received at the airport. Indeed, it was only at the aircraft door that the ceremonial guard of six BDF soldiers who had marched forward to take delivery of the coffin discovered that four men were more than sufficient. Instead of a full-length coffin fitting for a man, Botswana received

58. Daily News, 5 October 2000, p. 1. Emphasis added.

59. Personal communication. 
a small casket bearing the bones of somebody whom the Spanish authorities claimed to be El Negro. No explanation was forthcoming, or ever given, as to why bones and not a body were sent to Africa. In fact, Botswana and its officials were confronted with a fait accompli when the Spaniards confronted them at Sir Seretse Khama airport with a box of bones.

In the run-up to the repatriation, there had been rumours in the academic community that El Negro was going to be returned to Africa in a box, and not a coffin, but there were no indications that the returned remains would be such as they were ${ }^{60}$ Even Dr Arcelin, who had first alerted the world to the continued degrading display of a human being in one of Europe's museums at the close of the twentieth century, was saddened and disappointed by the changes that had been wrought upon what were the alleged remains of El Negro. His incredulous words were carried on the front page of Botswana's daily government newspaper, the Daily Nerw:

'The El Negro I have been seeing all along in Spain is different from what I see here. It was only two weeks back that I saw this man, he had some hair and black skin.' Arcelin could not tell what could have been done to the body. 'It does not depict the El Negro I fought for for so many years,' he said. He said it would not be wrong for one to claim that it is an anonymous skeleton. ${ }^{61}$

Arcelin was not the only person to voice his displeasure. It is no exaggeration to state that the thousands of people who came to pay their respects as the remains lay in state at the civic centre were shocked and angered by what they saw. Angry students, bearing placards and symbolically brandishing bows and arrows, thronged around the casket and demanded to know what had happened to the remains. A placard proclaimed, 'Is it too late for a PostMortem?????. ${ }^{62}$ Journalists described being accosted by youths who demanded to know 'why Botswana accepted just the skull without the rest of the body'. ${ }^{63}$

Even though academics, and Neil Parsons in particular, had conducted extensive research on the origins of El Negro, there remained a nagging doubt on the part of people in Botswana as to exactly who El Negro was. This was exacerbated when Botswana took possession of a few bones. Thus newspaper editorials could state: 'No one is 100 percent sure where he came from and which tribe, clan and family he belonged to. No one bothered to find out. ${ }^{64}$ No one could positively identify these bones, which could be from anyone. As an editorial noted, they could even belong to Mosarwa. ${ }^{65}$

60. Neil Parsons, pers. comm.

61. Daily News, 6 October 2000, p. 1. Emphasis added.

62. Mmegi, The Reporter, 6-12 October 2000, pp. 1-2; The Voice, 6-12 October 2000, pp. $1-2,6$.

63. Mmegi, The Reporter, 6-12 October 2000, p. 2.

64. The Vice, 6-12 October 2000, p. 6.

65. The Voice, 6-12 October 2000, p. 6. 
In addition to the issue of exactly who or what El Negro was, there were widespread rumours that Spain had made an extremely large amount of money from El Negro. There were demands for the payment of reparations for 'their ignominious deed of displaying El Negro' ${ }^{66}$ There were also more sinister rumours that argued that Spain had made money through the sale of El Negro's body and body parts, rumours that grew in strength in the light of the small bundle of bones which were presented to Botswana. Thus people, in referring to the remains on display in the civic centre, could shout:

This is an insult. The government should not have done that. The Spanish should have been made to bury the body themselves. Where is the money that they have made from selling the body? That we also want. The government has disappointed us. ${ }^{67}$

The belief that money had been made through the sale of El Negro's body, fits perfectly into already existent witchcraft discourse relating to the traffic in bodies and body parts.

In the end it must be considered that the government of Botswana was placed in a situation where it could not refuse. When its guard of honour marched to the plane, it and the people of Botswana as a whole believed that they would be taking delivery of a body; instead they took delivery of bones. In effect, there was nothing the Foreign Affairs Minister and the other dignitaries could do but accept these bones and continue with the proceedings. As Lt.-Gen. Merafhe had stated before the arrival of the bones:

Botswana was morally bound to accept the remains of El Negro to give him a decent and dignified burial on behalf of Africa and the Black race. . . [T] he question about the origins of El Negro was insignificant because the most important thing was to give him a decent burial and dignity as a human being. ${ }^{6}$

Off the record Merafhe, when challenged about the fact that not a body but a few bones had been returned, reacted in an upset and angry manner, but emphasized that there had been very little that could have been done, if Botswana wished to avoid a diplomatic incident. ${ }^{69}$ Those who presented the country with bones from which the flesh had been removed shamed the reputation of Botswana and its people. It was an insult felt and expressed by many.

66. Mmegi, The Reporter, 6-12 October 2000, p. 2.

67. Mmegi, The Reporter, 6-12 October 2000, p. 2.

68. Daily Newws, 4 October 2000, p. 1.

69. Personal communication from one of the academics involved in the ceremonies surrounding the return of El Negro. 


\section{El Negro and popular consciousness}

During the funeral service conducted for El Negro at the graveside in Tsholofelo Park, the minister officiating at the ceremony made what was probably an unconscious Freudian slip when he stated that El Niño had been a son of Africa who had now finally been allowed to return to the continent of his birth. ${ }^{70}$ In so doing the minister did express the truth, for El Negro was indeed a child of Africa, ${ }^{71}$ yet at the same time he gave voice to the presence in popular consciousness of the term El Niño and all that has come to be associated with this term.

In the second half of the nineteenth century Peruvian fishermen began referring to the periodic warming of the coastal waters off the South American Pacific coast at Christmas as El Niño, meaning 'The Child' or 'The Little One'. El Niño drove off the fish, yet caused extensive rainfall in the coastal deserts of South America. The term El Niño appeared in print for the first time in 1892 in a Peruvian scientific journal. ${ }^{72}$ In the course of the twentieth century it became increasingly apparent that El Niño, which is part of a meteorological phenomenon known as the El Niño Southern Oscillation, is one of the major determinants of global rainfall patterns. ${ }^{73}$ At intervals of between two and ten years, El Niño appears approximately 30 times every century. Throughout the world El Niño and its opposite La Niña have been blamed for all manner of catastrophes, whether extensive flooding in southern Africa, the failure of the monsoon in the Indian subcontinent, or the absence of rain in Australia. It would be no exaggeration to state that in much of the world at present El Niño and global warming are the two terms chosen to attempt to describe and explain weather conditions. Throughout 2000, as floods ravaged the southern half of Africa, they were consistently pulled out of the hat to explain what was happening. El Niño, in whatever way people believe it to be, has entered into the popular consciousness of much of the world, Botswana included.

In 2000 the island of Madagascar off the eastern coast of southern Africa was ravaged by no less than four cyclones. ${ }^{74}$ As the people of Madagascar struggled to deal with the devastation that befell them, the cyclones tended to peter out in the Mozambican Channel, but drenched southern Africa with more extensive rains than had ever been experienced before. In early

70. Neil Parsons, pers. comm.

71. Indeed, the placard erected at the grave of El Negro in Tsholofelo Park refers to him as a 'son of Africa'.

72. http://www.pbs.org/wgbh/nova/elnino/reach/1880.html.

73. A glance at materials dealing with El Niño as a natural phenomenon will indicate what a frighteningly magnificent event this actually is, an event that causes sea levels to rise no less than $150 \mathrm{~cm}$., transports more water than all the American great lakes combined, consumes more energy than all fossil fuels ever burnt, and so forth: http://www.pbs.org/wgbh/nova/elnino. 74. For a website which provides an overview of hurricanes that reached southern Africa in 2000, see http://weather.unisys.com/hurricane/s_indian/2000/index.html. 
February, Cyclone Leon developed just to the south of Sumatra, and traversed the Indian Ocean as a tropical storm. A few days before reaching Madagascar, it was upgraded to the status of a hurricane and renamed Eline. Eline travelled straight across Madagascar and the Mozambique Channel before it hit the Mozambican coast on 22 February with sustained winds of up to $130 \mathrm{mph} .{ }^{75}$ When Eline hit Mozambique an estimated 300,000 people were already homeless on account of earlier flooding. In Botswana, extensive rains had already left nine people dead and up to 90,000 homeless after destroying nearly 10,000 homes across half the country. ${ }^{76}$ It was therefore hardly surprising that the government began preparing for the expected arrival of Cyclone Eline. Members of the diplomatic community, development agencies, the business community and nongovernmental organizations were called to meetings and briefed as to the coming of Cyclone Eline and its expected consequences. Following one of the meetings an employee of the United Nations Development Programme in Botswana returned to brief her colleagues about the coming of devastating winds and rains, which, she said without blinking an eyelid, were caused by the impending arrival of an 'Alien'. In the first instance it was thought that she was joking, but on closer questioning it turned out that she really believed, not only in the undisputed existence of extra-terrestrial beings, but that an 'Alien', wreaking death and destruction in its path, was fast approaching the Republic of Botswana. ${ }^{77}$ Obviously the name of the cyclone, 'Eline', had become confused with the word 'Alien', a term loaded with all manner of meaning in popular consciousness. Once this occurred, 'Alien' entered into the realm of rumour, an alternative explanation as to what was happening in the world.

It is more than likely that in Botswana connotations of rain and weather, which are associated with the term El Niño, came to be transferred to the term El Negro. How one would actually show this to be the case is difficult to see, but, as the words of the minister officiating at the burial of El Negro indicated, the two terms could be and were unconsciously interchanged. The use of the term El Negro in a variety of different social settings, as indicated by its use by students, marriage guests, and funeral attendants, indicates the extent to which El Negro had entered the popular consciousness of people in Botswana. Here it nestled close to and probably alongside the other loaded term, El Niño, that had also entered the popular consciousness.

75. http://weather.unisys.com/hurricane/s_indian/2000/LEON_ELINE/track.dat. For an overview of the impact of Eline on Mozambique and southern Africa as a whole, http://www.mg.co.za/mg/news/2000feb2/24feb-moz_floods.html.

76. http://www.mg.co.za/mg/news/2000feb $2 / 22$ feb-floods.html.

77. Pers. comm., M. G. Janssen, a medical-anthropologist employed by one of the UN agencies in Gaborone. 


\section{'Radio Mall': rumour in Gaborone}

In the run-up to 1 January 2000, the BBC World Service broadcast a programme which claimed that down-town Gaborone had to be the quietest capital city on earth in which to celebrate the coming of the new millennium. Following the elections of early 2000, the newly elected president dryly noted that the elections had been peaceful and uneventful, and that he had no desire to see this change. Botswana is, indeed, what the Americans would call a 'laid-back' country. Peace and stability are two attributes that spring to mind, attributes which no one would like to see come to an end. This is not to claim, however, that Batswana are citizens cowed into submissive silence. Far from it; indeed, society and politics in Botswana are characterized by extensive and heated debates. The free media delight in raking across the coals failing politicians, corrupt businessmen, or opposition figures. The image of President Mogae being lambasted on national television by squatters in the settlement of Mogoditshane is a fair indicator of the extent to which press freedom is respected and encouraged in Botswana. In addition to its free press, Botswana, along with many other African states, subscribes to the informal news network known as Radio trottoir ('Pavement Radio'78) in francophone states, and 'Radio Mall' in Gaborone.

'Radio Mall' first started broadcasting in the early 1960s shortly after the 'Mall', a kilometre of low-rise buildings housing offices, embassies, shops, and banks, had been built in the new capital city of what would become the republic of Botswana. Radio Mall, like Radio trottoir in other countries, carried information too far-fetched, painful, or truthful to be carried in any other form of media. In the 1980s long before other media, Radio Mall carried hard news on forthcoming South African army raids, the successes of Umkhonto we Sizwe operations, and finally the collapse of the Mangope regime in the South African homeland of Bophutatswana. ${ }^{79}$ In addition, Radio Mall carried scandalous reports on the sexual peccadilloes of wellknown people. However, as Gaborone has continued to grow, 'Radio Mall' has become more and more of a misnomer. No longer do people meet and chat exclusively on the Mall; instead, as people have to commute from ever further away, conversation and news tend to be situated increasingly in and around the taxi ranks of Gaborone's public transport system.

It was here that in late December 2000 the first accurate reports of extensive levels of rainfall at Madikwe, three kilometres beyond the frontier in

78. Stephen Ellis, 'Tuning in to Pavement Radio', African Affairs 88, 352 (1989), pp.321-30.

79. Numerous people have noted how in the run-up to South African cross-border operations, rumours would fly around Gaborone. In some instances these rumours allowed people to ensure their safety and that of their loved ones by moving them from their usual places of residence. 
South Africa, were first heard on Radio Mall. ${ }^{80}$ It was here too that on 9 January 2001 the first reports surfaced on the way in which the remains of El Negro were preventing the rains from coming through to Gaborone and Botswana as a whole.

\section{The associations of El Negro}

Writing on reports dealing with the traffic in heads in southern Africa, Luise White has noted: 'My point here is . . . that the metaphorical is itself the material, and the ideas enshrined in popular consciousness thrive as popular consciousness. ${ }^{81}$

In terms of popular consciousness, El Negro came to be linked to the multitude of ideas relating to the natural weather phenomenon known as El Niño. In addition, El Negro, and the events surrounding the return of what were alleged to be his remains, came to be linked to a multitude of issues ranging from Bushmen, the sale of body parts, witchcraft, upset ancestors to corrupt politicians. In the conversations that took place in the taxis and Radio Mall of Gaborone the return of El Negro, in combination with one or more of the issues described above, came to be seen as being responsible for the absence of rain in Gaborone. In other words, a discourse that implicitly accepts and acknowledges the influence of the metaphysical and supernatural on everyday life, serves as an explanation as to why things occur in the way they do in the world. The words of Cyprian Fisiy, writing on sorcery, are equally relevant to the discourse in Botswana which includes the metaphysical and supernatural:

Sorcery discourse serves as an explanation why things go wrong in a community. These discourses provide the primary paradigm for explaining both fortune and misfortune. By using witchcraft discourses in this manner the community tries to understand why things happen in a particular way rather than how they happen. ... In one of the leading studies of witchcraft, Evans-Pritchard (1937:72) pointed out that while Azande are aware of the physical circumstances of accidents and disease, witchcraft discourses explain why a particular sufferer and no other was the victim. 'Witchcraft explains why events are harmful to man and not how they happen. ${ }^{82}$

Like all those who watch the daily news broadcasts and weather forecasts on national television, the people living in Gaborone know about high pressure zones and so forth; like their contemporaries in northern Europe, they believe they know how the weather works. However, they do not know why, and it is this fundamental issue that they seek to answer: in this instance,

80. Large numbers of taxis commute daily from Gaborone to Johannesburg and back, providing up-to-date reports on all sorts of developments, including in this instance that extensive rains had fallen just beyond the frontier in South Africa.

81. White, 'The traffic in heads', p. 336.

82. Fisiy, 'Law out of context', p. 7. 
'Why is it not raining in Gaborone?'. It was in attempting to answer this question that people linked the coming of El Negro, in conjunction with one or more of the issues - Bushmen, body parts and witchcraft, upset ancestors, and corrupt politicians - to the absence of rain.

At times the El Negro rumour sought to emphasize that El Negro had been a Bushman. ${ }^{83}$ No doubt this strand of rumour came to be reinforced every time correspondents and media dismissed the available evidence and chose to refer to El Negro as a Bushman. ${ }^{84}$ Thus, with blatant disregard for the results of earlier investigations and reports, the large circulation South African daily newspaper, The Star, carried as one of its front-page headlines, 'Botswana welcomes return of Bushman's body used as colonial exhibit'. As to why The Star should have chosen to misinform its reading public, that became apparent in the last paragraphs of the article: 'Bushmen still living in Botswana's Central Kalahari Game Reserve have over the years battled the government over its plans to resettle them and make way for tourist development.' 85

In effect, the choice of The Star to use the return of the remains of El Negro to highlight opposition to the planned removal of Bushmen from the Central Kalahari, served merely to emphasize once again the position of Bushmen as the inhabitants of the bush. That is, to paraphrase Gordon, the qualities of Bushmen as being grounded not in humanity but in animality. ${ }^{86}$ As the anthropologists Jean and John Comaroff have stated:

It will be remembered . . . that Tswana social architecture distinguished the town from the bush. The wild was the threatening realm of spirits, plants, and animals of unruly potential. It provided the vital ingredients for both healing and sorcery, and, most important, was the habitat of Sarwa ('bush' people) and other (less than social) clients and serfs. ${ }^{87}$

The bush is seen as the site par excellence of magic. In present-day Botswana Bushmen continue to be seen as the epitome of the bush, and all that it entails. In the public mind they alone live and survive in the bush, and as such they are able to control the extreme powers that reside in the

83. I am well aware of the various pejorative names given to the descendants of the first inhabitants of southern Africa. In this instance I follow the example of Robert Gordon, who noted, "The term Bushman is ... a "Lumpen category" into which all those who failed to conform or acquiesce were dumped. It was not an ethnic group but a sociopolitical category derived from the wider setting'. The Bushman Myth:The making of a Namibian underclass (Westview Press, Boulder, CO, 1992), p. 6.

84. In one instance, whilst being interviewed live on Dutch radio, I was asked to tell listeners about 'dat kleine bosjesmannetje' ['That little Bushman']. Unfortunately the literal translation into English fails to bring across the condescension implied in the double use of the diminutive in the Dutch. Neil Parsons reported similar frustrations in most of the more than 35 interviews which he conducted with the media at the time of El Negro's funeral.

85. The Star, 5 October 2000.

86. Gordon, The Bushman Myth, p. 2.

87. Comaroff and Comaroff, Revelation and Revolution, Vol. 1, pp. 152-3. 
bush. Given the above, it follows that the state funeral, only the second in Botswana's history, of, if the rumours are to be believed, a Bushman would indicate the dabbling of the powers that be in the most extreme forms of magic.

There is also a clear association between the arrival in Botswana of El Negro and local ideas about human body parts. Luise White has written on the traffic in body parts, and heads in particular, in the southern African region. Her work, though it focuses primarily on events in Zimbabwe, reflects discourse in Botswana. As White pointed out:

... proper burials released spirits from their corporeal bodies so that grave robbing produced a spirit's wrath and useless organs. Body parts could be removed, mixed, and given to another human being, but they never lost their bodily integrity: they never ceased to belong to the person into whom they were born, regardless of whether that person was dead or alive. ${ }^{88}$

From the little that we know of El Negro, we can be certain that, when he was buried the first time, he was buried properly in accordance with Tswana tradition. ${ }^{89}$ In other words, unless the Verraux brothers deployed powerful protective medicines of their own when they dug him up, his spirit (badimo) would have come forth to vent its wrath. In addition, his spirit would have watched over and followed his various body parts. Discussing El Negro, an informant noted that, after having been dug up, El Negro must have said, 'What is this place, where am I now, who has done this to me?" ${ }^{90} \mathrm{El}$ Negro would have been well aware of where he had been buried by his relatives and anxious to return there intact. ${ }^{91}$

In 1993, prior to the repatriation of El Negro, a post-mortem, which included a complete body scan, was completed, the conclusions of which were that the young man had died of a pulmonary disease. ${ }^{92}$ It stands to reason that, for such a conclusion to be reached, there must have been a fair amount of tissue still in existence. Indeed, the photographs of El Negro in Banyoles clearly show that, whilst on display, the young man still had his hair and nails. In the light of the above, one of the most shocking aspects regarding the return of El Negro's remains to Botswana was the fact that, instead of a body, Botswana took delivery of a few bones. This extended beyond the immediate embarrassment felt by all and expressed by a few, of

88. White, 'The traffic in heads', p. 329.

89. Research conducted by Neil Parsons of the history department at the University of Botswana has brought to light that El Negro was buried along with a small leather bag containing small glass beads, seeds, and small bones. In the words of Parsons, 'It could indicate that he was some kind of ngaka (traditional doctor)'. http://ubh.tripod.com/afhist/elnegro/ eln07.htm.

90. Meiki Maotwe, pers. comm. 20 April 2001.

91. This aspect ties into a later question as to how a person can have no relatives.

92. http://ubh.tripod.com/afhist/elnegro/eln-pm.htm. 
expecting a body and receiving some bones, into the realm of witchcraft and trade in body parts. Not surprisingly people asked the obvious questions: what had happened to the body, where were the organs, the hair and the nails, and the remaining bones? Where were his clothes, and his grave goods? What had happened to these things, and who had ordered that El Negro be transformed into a pitifully small pile of bones? These are questions that remain unanswered, not only for those who commute in Gaborone's taxis, but also those in the highest social echelons. ${ }^{93}$ In a country where ritual murder, and the traffic and use of human body parts in sorcery, are a reality, it cannot be considered surprising that people conclude that the same thing has happened to El Negro. Even if those involved deny that they have used the remains of El Negro for ritual purposes, the valid question as to what they did with his remaining body parts, remains outstanding.

\section{Spirits, ancestors, politicians}

Initially, the issue of El Negro's spirit in exile in Spain was of no interest to those I interviewed. What was important was that the highly troubled spirit had accompanied some of its body to Botswana and to its grave at Tsholofelo Park. Informants were generally agreed that his spirit accompanied all parts of the dismembered body, unless it had been prevented from doing so by the use of strong medicine. As such, at least one informant was anxious to know whether Spaniards were legkoa (Whites) and whether or not El Negro's spirit would haunt those who had stripped his remaining body parts before his journey from Spain to Botswana. ${ }^{94}$ As such, for most informants, in view of the fact that the materials buried at Tsholofelo Park were not medicines associated with witchcraft, but were indeed the mortal remains of El Negro, there was no doubt that these remains had been accompanied by the spirit of El Negro - a spirit whose remains had been laid to rest in foreign soil and without the ministrations of his relatives, and that would therefore continue to roam seeking retribution and to be laid to rest properly.

The aspect of El Negro being without family, except in the broadest sense of being a 'son of Africa', was particularly troubling to many people. How could it be that these mortal remains had no relatives, since all humans have family members? In a sense this line of reasoning followed that expressed by Zimbabweans when, under the auspices of the Zimbabwean government, a monument to the unknown soldier was unveiled in 1998: 'former guerrillas who were present wondered how a soldier could be unknown - they

93. One university history lecturer wondered what had happened to the steel, or copper, frame that had supported El Negro throughout the 170 years during which he had been displayed. One can also ask what happened to the materials with which he had been stuffed.

94. Meiki Maotwe and Dikaledi, 18 April 2001. 
wanted to know who he was, where he was from, and they wondered what purpose a single soldier served' ${ }^{95}$ Why was this person without relatives being accorded a state funeral? In addition, if he came from what is now South Africa, why did the South Africans not wish to bury El Negro? What, effectively, was it that the South Africans knew about El Negro that prevented them from burying his remains in South Africa?

In a sense the differing strands of thought relating to El Negro outlined above all come together in popular ideas expressed with regard to politicians. Since independence the city of Gaborone has consistently voted for opposition parliamentarians in both local and general elections, and is known to be the centre of organized political opposition to the ruling party. Even so, fractious political infighting within the opposition parties has consistently ensured that the Botswana Democratic Party has been able to win convincingly at every national election. The result is that Gaborone, though it is the site of the most concerted opposition to the ruling party, is the seat of government led by the ruling party. ${ }^{96}$ Not surprisingly, this has led to consistent debate within Gaborone and a generous dose of scepticism on the part of the public with regard to the official pronouncements of the government - in other words, an atmosphere in which rumour flourishes.

With regard to the state funeral of El Negro, many people demanded to know why the government should spend the amounts of money it did on the remains of a man without family and with an unknown past. In addition, and on a far more sinister level, many people believed that the government had either received or paid large sums of money for what was effectively witchcraft medicine - medicine which ensured that the rain stayed away and increased the poverty and dependence of the people at the mercy of those in power. The consistent refrain in both these strands of thought, be it that El Negro was only a mortal, or that what was buried was medicine, was that the government had paid out large amounts of money on El Negro at the expense of its own people.

\section{Conclusion}

It will be clear that, in dealing with the burial of El Negro at Tsholofelo Park, there were a number of differing ideas as to what exactly had come to be buried there and why. When El Negro arrived in Botswana people were faced with an array of questions. Was it merely the mortal remains of a man who died 170 years ago, was it the mortal remains of a man whose spirit

95. Jocelyn Alexander, JoAnn Mcgregor and Terence Ranger, Violence and Memory: One hundred years in the 'Dark Forest' of Matabeleland (James Currey, Oxford, 2000), p. 262.

96. Wayne Edge and Mogopodi Lekorwe (eds), Botswana: Politics and society (Pretoria, 1998), and Pula: Botswana fournal of African Studies 14, 1 (2000), special issue: Elections and Democracy in Botswana. 
had had to watch his body being robbed, gutted, stuffed, stripped, and displayed, was it powerful witchcraft that had been purchased by politicians from the Spaniards, was it the pride and goodwill of Botswana, or was it a combination of all these things that came to be buried at Tsholofelo Park?

When rain failed to arrive in early 2001, rumours started that linked the absence of rain to the presence of El Negro. Apart from slips of the tongue and the unconscious linking of El Negro to 'El Niño', these rumours, which existed within popular consciousness and were debated in the everyday life of Gaborone commuters, came to be linked to all manner of already existing ideas that related to one or a combination of issues dealing with Bushmen, spirits and ancestors, witchcraft, sorcery and the trade in body parts, and politicians. In other words, ideas relating to El Negro came to be incorporated and discussed within already existing ideas as to how the world works and is ordered.

The funeral of El Negro and the subsequent absence of rain confirmed to many what they already believed. In a circular argument, people argued that the politicians were powerful and rich precisely because they were involved in witchcraft, and the absence of rain was evidence of this involvement. The El Negro rumours gave people the opportunity to articulate their deep-seated grievances vis-à-vis those in power at a number of levels. However, these grievances, whether the waste of government money on a Bushman, or a homeless person with no family, or witchcraft medicines for already powerful politicians, all relate to one issue, that those in power had failed to care for those without power. The spending of vast sums of money on the remains of an unknown person was seen as unjust. El Negro may very well have deserved to be buried with full pomp and ceremony by the Botswana state, but when the expected arrival and display of a full-sized corpse failed to materialize, people began to question the validity of El Negro and their government's desire to accord the remains the status which it did. In effect, it can be said that the rumours were the expression of public dissatisfaction at having been hoodwinked by the Spanish. Far from the return of El Negro being a return with honour, the arrival of a small casket of bones signalled to one and all that all was not well. The rumours that followed in early 2001 were a way in which people could express and entertain their distrust of those in power in Botswana, who had allowed Botswana to be shamed for their own selfish interests and not those of the people. 